\title{
Penerapan Blended Learning Menggunakan Media Youtube Podcast Dengan Melibatkan Birokrat Dan Praktisi Pendidikan Nonformal Dalam Meningkatkan Hasil Belajar Mahasiswa Program Studi Pendidikan Nonformal
}

\author{
Sofino $^{1}$; Bayu Pradikto ${ }^{2}$ \\ ${ }^{1,2}$ Prodi Pendidikan Nonformal, FKIP Universitas Bengkulu, Indonesia \\ e-mail: sofino@unib.ac.id
}

Received: 13 August 2021; Revised: 02 October 2021; Accepted: 14 December 2021

DOI: http://dx.doi.org/10.37905/aksara.8.1.503-512.2022

\begin{abstract}
Abstrak
Tujuan penelitian ini untuk melakukan perbaikan pembelajaran di Program Studi Pendidikan Nonformal pada mata kuliah analisis kebijakan pendidikan nonformal dengan menggunakan model blended learning menggunakan media youtube podcast dengan melibatkan birokrat dan praktisi pendidikan nonformal. Penelitian menggunakan penelitian tindakan kelas yang dilakukan secara kolaboratif antara peneliti dengan dosen pengampu mata kuliah. Mahasiswa yang terlibat berjumlah 27 orang dari semester 5 kelas A tahun ajaran 2020-2021. Hasil penelitian pada siklus 1 sebesar 71,6\% atau berada pada kriteria tinggi, siklus 2 sebesar $82,6 \%$ atau berada dalam kriteria tinggi dan siklus 3 sebesar 87,2\% atau berada dalam kriteria sangat tinggi. Keterampilan dosen mengalai peningkatan, pada siklus 1 sebesar 73,17\% atau kriteria baik, siklus 2 sebesar 80,5\% atau kriteria baik dan siklus 3 sebesar 83,17\% atau kriteria baik. Hasil belajar mahasiswa juga mengalami peningkatan, pada siklus 1 ketuntasan minimal sebesar 66,67\% atau belum tuntas, pada siklus 2 ketuntasan minimal sebesar 77,78\% belum tuntas, dan siklus 3 sebesar 92,59\% tuntas. Kesimpulan bahwa penerapan blended learning menggunakan media youtube podcast dengan melibatkan birokrat dan praktisi pendidikan nonformal dapat meningkatkan aktivitas belajar mahasiswa, meningkatkan keterampilan mengajar dosen dan meningkatkan hasil belajar mahasiswa semester 5 kelas A pada mata kuliah analisis kebijakan pendidikan nonformal.
\end{abstract}

Kata Kunci: Blended Learning, Youtube, Podcast, Hasil Belajar

\begin{abstract}
The purpose of this study is to improve learning in the Non-formal Education Study Program in the subject of non-formal education policy analysis using amodel blended learning using youtube podcast media by involving bureaucrats and non-formal education practitioners. The research uses classroom action research which is carried out collaboratively between researchers and subject lecturers. The students involved were 27 people from semester 5 of class A for the 2020-2021 academic year. The results of the research in cycle 1 were $71.6 \%$ or were in high criteria, cycle 2 was $82.6 \%$ or were in high criteria and cycle 3 was $87.2 \%$ or were in very high criteria. The skills of the lecturers have increased, in cycle 1 of $73.17 \%$ or good criteria, cycle 2 of $80.5 \%$ or good criteria and cycle 3 of $83.17 \%$ or good criteria. Student learning outcomes also increased, in cycle 1 the minimum completeness was $66.67 \%$ unfinished, in cycle 2 the minimum completeness was $77.78 \%$ unfinished, and cycle 3 was $92.59 \%$ completed. The conclusion is that the application of blended learning using YouTube podcast media by involving bureaucrats and nonformal education practitioners can increase student learning activities, improve lecturers' teaching skills and improve student learning outcomes in the 5th semester of class A in the non-formal education policy analysis course.
\end{abstract}

Keywords: Blended Learning, Youtube, Podcasts, Learning Outcomes 


\section{PENDAHULUAN}

Di era digital saat ini pembelajaran tidak terlepas dari peran teknologi. Teknologi dan ilmu pengetahuan adalah satu rangkaian yang tidak dapat dipisahkan. Perkembangan teknologi yang cepat, berdampak pada pola pembelajaran. Berbagai satuan pendidikan mulai mengembangkan dan menerapkan pembelajaran berbasis elektronik (e-learning) atau dengan menggabungkan berbagai teknik pembelajaran (blended learning). Hal ini tentu saja untuk mencapai tujuan pembelajaran yang maksimal dengan memanfaatkan teknologi.

Dibalik kemudahan yang ditawarkan pembelajaran online terdapat permasalahanpermasalahan dalam pelaksanaannya. Rohamanu, dkk (2020) menyatakan bahwa problem teknis antara lain akses jaringan yang tidak merata, kuota yang terbatas, platform e-learning yang tidak memadai, serta kemampuan dosen dalam menyampaikan materi perkuliahan. Ada kecenderungan yang muncul selama pembelajaran daring dilakukan yaitu penurunan minat dan kemampuan akademik mahasiswa karena jenuh dengan gaya belajar yang monoton. Hal ini diungkapkan oleh Andini (2020) bahwa dampak negatif dari pembelajaran daring adalah berkurangnya minat belajar siswa karena bosan dan menumpuknya tugas-tugas perkuliahan. Salah satu penyebab dari menurunnya minat dan kompetensi mahasiswa dalam pembelajaran di masa pendemi covid-19 adalah karena penggunaan aplikasi/media video converence kurang efektif jika diterapkan pada mata $\mathrm{kuliah} /$ mata pelajaran tertentu yang sejatinya mengharuskan mahasiswa untuk melakukan kegiatan langsung atau analisis tingkat tinggi. Setiani (2020) menyatakan bahwa masih banyak kendala dalam pembelajaran di masa pendemi covid-19 dan setelah pandemic covid-19, sehingga hasilnya kurang efektif bila hanya menggunakan zoom/ aplikasi video conference lainnya.

Mata kuliah analisis kebijakan pendidikan nonformal merupakan salah satu mata kuliah inti program studi. Tujuan mata kuliah ini mengarahkan mahasiswa agar mampu memahami konsep, teori dan ruang lingkup kebijakan pendidikan nonformal serta mampu menganalisis kebijakan pada tiga jalur pendidikan (formal, nonformal dan informal) yang saling berkaitan, serta memahami peran masing-masing sektor dan kegiatannya, serta mampu menganalisis permasalahan terkini tentang arah kebijakan dan implementasi pendidikan nonformal dari berbagai sudut pandang sosial, budaya, politik, ekonomi, hukum, iptek serta mampu memberikan alternatif pemecahan masalah dan mampu memberikan masukan maupun kritikan terhadap kebijakan-kebijakan pemerintah dalam bidang pendidikan nonformal.

Berdasarkan evaluasi belajar yang dirilis oleh di aplikasi Sistem Evaluasi Pembelajaran (SIEPEL) Universitas Bengkulu semester ganjil tahun ajaran 2020/2021, dan dilakukan analisis ternyata 59,6\% mahasiswa menginginkan peningkatan kualitas pembelajaran atau perbaikan pembelajaran dengan alasan pembelajaran yang monoton, kurang memanfaatkan teknologi yang hanya ceramah dan diskusi di virtual zoom, kurang efisien dalam penggunaan waktu, disiplin waktu dan pola penilaian yang kurang transparan. Selain itu, rata-rata kepuasan mahasiswa terhadap mata kuliah ini tergolong rendah jika dibandingkan dengan mata kuliah Program Studi pada semester lima (5) lainnya dan dibawah rata-rata mata kuliah program studi (rata-rata poin 4,288).

Tren youtube podcast memang sedang marak dikalangan milenial dengan kontenkonten yang menghibur dan memberikan informasi. Faktanya memang masih belum terlalu banyak konten di youtube podcast yang membahas tentang edukasi, jumlahnya 
masih kalah jumlahnya jika dibandingkan dengan konten hiburan. Namun perkembangan konten youtube edukasi jika dikelola dengan baik dan menarik tentu akan terus berkembang dan menemukan pasarnya sendiri. Beberapa chanel youtube edukasi yang memiliki subscriber dan viewer ratusan ribu bahkan jutaan, antara lain:

Tabel 1. Chanel Youtube Konten Edukasi

\begin{tabular}{|c|c|c|c|}
\hline No. & Nama Channel & $\begin{array}{l}\text { Subscribe/ rata-rata } \\
\text { Viewer }\end{array}$ & Pengelola Konten \\
\hline 1 & Nihongo Mantappu & 6,77 juta/ 1 juta & Jerome Polin \\
\hline 1 & Hujan Tanda Tanya & $\begin{array}{l}470 \text { ribu/100 ribu }-200 \\
\text { ribu }\end{array}$ & Diaspora Indonesia \\
\hline 2 & Pahamifi & $93 \mathrm{ribu} / 10 \mathrm{ribu}-20 \mathrm{ribu}$ & Pahamifi Team \\
\hline 3 & Kok-Bisa? & 2,7 Juta/200 ribu & KokBisa Team \\
\hline 4 & SainsBro & $87 \mathrm{ribu} / 2 \mathrm{ribu}$ & SainsBro Team \\
\hline
\end{tabular}

Sumber: data chanel perbulan Mei 2021

Youtube dan podcast jika digunakan dalam kegiatan pembelajaran cukup memberikan dampak positif. Penggunaan youtube dapat meningkatkan motivasi belajar dan pemahaman konsep peserta didik serta lebih menarik dan interaktif (Iwantara, dkk, 2014; Tutiasri, dkk, 2020). Begitupun podcast, mampu menjadi alternatif media pembelajaran yang inotif meningkatkan wawasan dan pemikiran peserta didik (Rachmawati, dkk, 2019; Zellatifanny, 2020; Fadillah, dkk 2017).

Youtube Podcast dapat menjadi perpaduan yang cocok untuk digunakan dalam pembelajaran. Youtube menjadi visual dan audio visual langsung, sedangkan podcast sebagai audio langsung yang mampu disimpan dalam siaran channel podcast yang sewaktu-waktu bisa didengarkan kembali. Ini berarti perpaduan ini dapat menjadi jejak digital proses pembelajaran yang menyenangkan dan aktual, bahkan sewaktu-waktu bisa digunakan kembali dan disebarluaskan. Pembelajaran dengan menghadirkan orang-orang yang kompeten yang langsung bersinggungan dengan isu tertentu (praktisi dan/atau birokrat), dipadukan dengan akademis (dosen) maka akan menghasilkan diskusi yang menarik dan berbobot. Ini lah yang diharapkan dalam pembelajaran blended learning, yang mana mahasiswa mendapat pengalaman langsung dari orang-orang yang terlibat di dalam isu-isu tertentu dalam dunia pendidikan.

Maka untuk semester ganjil tahun ajaran 2021/2022 untuk mata kuliah Analisis Kebijakan Pendidikan Nonformal, perlu dilakukan perbaikan pembelajaran, terutama dengan blended learning menggunakan media Youtube Podcast yang saat ini sedang digemari anak-anak muda dalam memperoleh informasi di era digital.

\section{METODE PENELITIAN}

Metode yang digunakan adalah penelitian tindakan kelas (classroom action research), yang dilakukan secara kolaboratif antara peneliti dengan dosen pengampu mata kuliah Analisis Kebijakan Pendidikan Nonformal. Penelitian ini menggunakan model blended learning dengan menggunakan media youtube podcast dengan narasumber melibatkan praktisi dan birokrat pendidikan nonformal. Responden merupakan mahasiswa semester 5 kelas A Program Studi Pendidikan Nonformal semester ganjil tahun ajara 2021/2022 yang berjumlah 27 orang. Desain penelitian ini mengadopsi desain yang dikembangakan oleh Kemmis dan Mc Taggart (1988:11) 
dengan tahapan: 1) Planning, 2) Act and Oberve, 3) Reflektion.

Analisis hasil belajar mahasiswa dihitung jumlah skor pada masing-masing mahasiswa dan didistibusikan pada rentang nilai, sehingga diperoleh sebagai berikut:

Tabel 2. Pedoman penilaian

\begin{tabular}{ll}
\hline Interval nilai & Kriteria \\
\hline $86-100$ & Sangat baik \\
$75-85$ & Baik \\
$60-75$ & Cukup \\
$55-59$ & Kurang \\
$\leq 54$ & Sangat kurang \\
\hline
\end{tabular}

Sumber: Purwanto (2006:103)

Hasil belajar dapat diukur dengan menggunakan rumus:

Nilai rata-rata mahasiswa, $X=\frac{\sum x}{n}$

Diketahui $X=$ nilai rata-rata akhir mahasiswa; $\sum \mathrm{x}=$ jumlah nilai mahasiswa pada mata kuliah analisis kebijakan PNF; $\mathrm{n}=$ banyaknya mahasiswa.

Persentase ketuntasan belajar klasikal mahasiswa dapat dihitung dan dianalisa dengan rumus berikut:

$\mathrm{KB}=\frac{N s}{N} x 100 \%$

Diketahui, $\mathrm{KB}=$ ketuntasan belajar klasikal; $\mathrm{N}=$ Jumlah mahasiswa; $\mathrm{Ns}=$ Jumlah mahasiswa yang memiliki nilai di atas standar ketuntasan. (Sudjana, 2001).

\section{HASIL PENELITIAN DAN PEMBAHASAN}

Berdasarkan hasil pengamatan terhadap aktivitas mahasiswa selama mengikuti pembelajaran, maka diperoleh data sebagai berikut:

Tabel 3. Hasil Data Observasi Aktivitas mahasiswa pada tiap siklus

\begin{tabular}{lllllll}
\hline \multicolumn{3}{l}{ Siklus } & & & & \\
Aspek & I & & II & & III & \\
& $\%$ & Kriteria & $\%$ & Kriteria & $\%$ & Kriteria \\
\hline 1 & 67 & Sedang & 80 & Baik & 89 & Sangat Baik \\
2 & 65 & Sedang & 78 & Baik & 80 & Baik \\
3 & 87 & Sangat Baik & 90 & Sangat Baik & 95 & Sangat Baik \\
4 & 74 & Baik & 89 & Sangat Baik & 88 & Baik \\
5 & 65 & Sedang & 76 & Baik & 84 & Baik \\
\hline Jumlah & 358 & & 413 & & 436 & \\
\hline Rata- & 71,6 & Baik & 82,6 & Baik & 87,2 & Sangat baik \\
rata & & & & & & \\
\hline
\end{tabular}

Berdasarkan hasil analisis observasi yang dilakukan observer, diperoleh rata-rata skor pada siklus 1 sebesar 71,6\% atau dalam kategori baik, hal ini mengindikasikan bahwa pada siklus 1 aktivitas mahasiswa sudah baik, walaupun pada beberapa aspek masih menjadi catatan, khususnya pada aspek 1 dan 2, yaitu pada tahap orintasi dan tahap merumuskan hipotesis sederhana. Pada siklus 2 dilakukan perbaikan terhadap 
kekurangan pada siklus sebelumnya. Hasilnya terjadi peningkatan rata-rata persentase aktivitas mahasiswa sebesar $11 \%$ sehingga rata-rata aktivitas pada siklus 2 menjadi $82,6 \%$. Pada siklus 2 sebenarnya sudah baik dan meningkat secara signifikan, namun karena harus mengikuti proses siklus selanjutnya sesuai dengan tahapan hasil belajar, maka dilanjutkan ke siklus 3. Siklus 3 dilakukan untuk memperbaiki kekurangan pada siklus sebelumnya, sehingga diperoleh data rata-rata aktivitas mahasiswa sebenar $87,2 \%$ atau dalam kategori sangat baik. Hal ini mengindikasikan mahasiswa semakin nyaman dan memicu keaktifan mahasiswa ketika belajar dengan menggunakan model blended learning dengan media youtube podcast. Aktivitas mahasiswa mengalami peningkatan pada setiap siklusnya.

Berikut dijabarkan hasil analisis data obervasi keterampilan dosen dalam mengajar pada setiap siklus:

\section{Tabel 4. Hasil Data Observasi Keterampilan Dosen Mengajar Pada Tiap Siklus}

\begin{tabular}{lllllll}
\hline \multicolumn{3}{l}{ Siklus } & & & & \\
\\
Aspek & I & & II & & III & \\
& $\%$ & Kriteria & $\%$ & Kriteria & $\%$ & Kriteria \\
\hline & 74 & Baik & 81 & Baik & 83 & Baik \\
2 & 75 & Baik & 83 & Baik & 84 & Baik \\
3 & 82 & Baik & 88 & Sangat & 90 & Sangat Baik \\
4 & 70 & Baik & 78 & Baik & 83 & Baik \\
5 & 68 & Sedang & 74 & Baik & 76 & Baik \\
6 & 70 & Sedang & 79 & Baik & 83 & Baik \\
\hline Jumlah & 439 & & 483 & & 499 & \\
\hline Rata- & 73,17 & Baik & 80,50 & Baik & 83,17 & Baik \\
rata & & & & & & \\
\hline
\end{tabular}

Berdasarkan hasil analisis data observasi yang dilakukan observer yang merupakan dosen senior Program Studi Pendidikan Nonformal FKIP Universitas Bengkulu, diperoleh rata-rata skor pada siklus 1 sebesar $73,17 \%$ atau dalam kriteria baik, hasil ini mengindikasikan bahwa pada siklus 1 keterampilan mengajar dosen sudah baik, walaupun pada beberapa aspek masih menjadi catatan, khususnya pada aspek 5 yaitu pada aspek pengujian hipotesis yaitu kemampuan membimbing mahasiswa dalam upaya memecahkan permasalahan pembelajaran, kemampuan mengarahkan mahasiswa dalam memecahkan masalah berdasarkan data dan fakta yang telah diperoleh; dan pada aspek 6 yaitu kemampuan menyimpulkan yaitu kegiatan malekukan refleksi yang melibatkan mahasiswa dan berdasarkan data dan fakta yang telah diperoleh. Pada siklus 2 dilakukan perbaikan untuk memperbaiki kekurangan pada siklus sebelumnya. Siklus 2 diperoleh hasil peningkatan rata-rata persentase keterampilan mengajar dosen meningkat sebesar 7,33\% menjadi 80,50\%. Pada siklus 2 sebenarnya sudah baik dan meningkat secara signifikan, namun karena harus mengikuti proses siklus selanjutnya sesuai dengan tahapan hasil belajar, maka dilanjutkan ke siklus 3. Siklus 3 dilakukan untuk memperbaiki kekurangan pada siklus sebelumnya, sehingga diperoleh data rata- 
rata keterampilan mengajar dosen sebenar $83,17 \%$ atau dalam kriteria baik. Hal ini mengindikasikan dosen semakin nyaman dalam melakukan kegiatan belajar mengajar ketika menggunakan model blended learning dengan media youtube podcast. Keterampilan dosen dalam mengajar mengalami peningkatan pada setiap siklusnya.

Berikut dijabarkan hasil belajar mahasiswa pada mata kuliah Analisis Kebijakan Pendidikan Nonformal semester 5 kelas A pada setiap siklusnya:

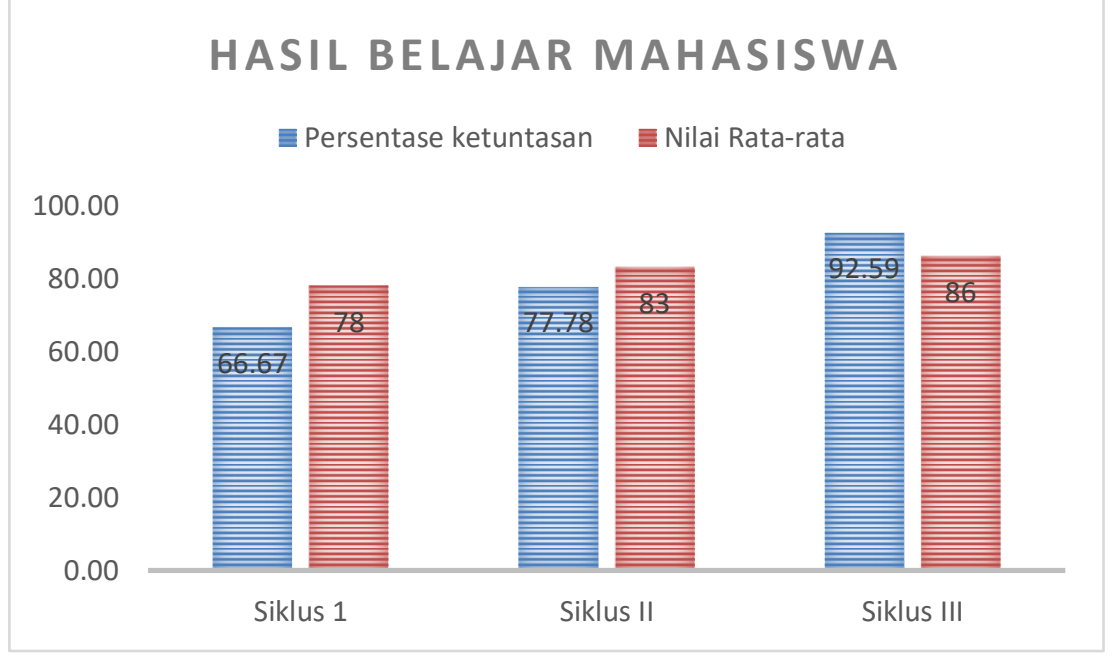

\section{Gambar 1. Hasil Belajar Mahasiswa}

Hasil belajar mahasiswa pada siklus 1 diperoleh nilai rata-rata mahasiswa sebesar 78 dengan persentase ketuntasan sebesar $66,67 \%$ atau masuk kriteria cukup. Berdasarkan hasil tersebut maka persentase pada siklus 1 dikatakan belum tuntas karena masih di bawah $85 \%$ mahasiswa yang mendapat nilai di $\geq 75$. Refleksi dilakukan oleh dosen mata kuliah untuk memperbaiki kendala pada siklus 1 .

Pada siklus 2 didapat hasil rata-rata nilai mahasiswa sebesar 83 atau sama dengan ketuntasan sebesar $77,78 \%$. Hal ini berarti pada siklus 2 juga belum memenuhi kriteria persentase ketuntasan karena belum memenuhi persentase ketentasan belajar sebesar $85 \%$. Artinya hanya 21 orang mahasiswa yang medapat nilai $\geq 75$, sehingga perlu dilakukan siklus 3 .

Pada siklus 3 didapat hasil rata-rata nilai mahasiswa sebesar 86 dengan rata-rata persentase ketuntasan minimum sebesar 92,59\%. Hal ini berarti siklus 3 dinyatakan tuntas, kerena telah di atas $85 \%$ mahasiswa melewati nilai ketuntasan minimal. Hal ini berarti telah ada 25 orang mahasiswa dari total 27 orang telah memenuni nilai ketuntasan minimal.

\section{Pembahasan}

Berdasarkan hasil penelitian yang dilakukan pada mahasiswa Program Studi Pendidikan Nonformal Fakultas Keguruan dan Ilmu Pendidikan Universitas Bengkulu semester 5 kelas A tahun ajaran 2021-2022 dengan jumlah responden sebanyak 27 orang, maka dapat dirangkum hasil sebagai berikut: 

Tabel 5. Rangkuman Aktivitas Mahasiswa, Keterampilan
Dosen dan Hasil Belajar Mahasiswa pada Setiap Siklus

\begin{tabular}{|c|c|c|c|c|c|}
\hline \multirow[t]{2}{*}{ Siklus } & \multirow{2}{*}{$\begin{array}{l}\text { Persentase } \\
\text { ketuntasan } \\
\text { Belajar }\end{array}$} & Aktivi & as Mahasiswa & $\begin{array}{l}\text { Ketera } \\
\text { Dosen }\end{array}$ & npilan \\
\hline & & r skor & Kategori & r skor & Kategori \\
\hline I & 66,67 & 71,6 & Baik & 73,17 & Baik \\
\hline II & 77,78 & 82,6 & Baik & 80,5 & Baik \\
\hline III & 92,59 & 87,2 & Sangat baik & 83,17 & Baik \\
\hline
\end{tabular}

Peningkatan hasil belajar mahasiswa pada mata kuliah Analisis Kebijakan Pendidikan Nonformal merupakan hasil dari terobosan perkuliahan yang mampu meningkatkan aktivitas belajar mahasiswa menjadi lebih aktif dan kritis, mampu meningkatkan keterampilan dosen dalam mengajar, mendapat bimbingan dari dosendosen senior, dan tentunya belajar dari kekurangan-kekurangan pada setiap siklus. Terjadinya peningkatan aktivitas belajar, keterampilan dosen dan hasil belajar mahasiswa dengan menggunakan media Youtube Podcast dengan melibatkan birokrat dan praktisi pendidikan nonformal. Dalam proses pembelajaran, mahasiswa melihat video youtube podcast dengan seksama dan dalam suasana belajar yang kondusif karena bisa diputar berulang kali, dan materi yang disampaikan lebih update dan sesuai dengan isu pendidikan nonformal dari praktisi dan arah kebijakan pendidikan nonformal dari birokrat.

Kegiatan belajar mengajar memanfaatkan teknologi yang dekat dengan mahasiswa membuat mereka jadi lebih familiar dan tidak kaku dalam penggunaannya, sehingga informasi yang disampaikan jadi dapat dengan mudah diterima oleh mahasiswa. Youtube dan podcast sebagai media pembelajaran tentu dapat meningkatkan hasil belajar dan aktivitas mahasiswa bila digunakan dengan tepat. Setiadi, Azmi dan Indrawadi (2019) mengungkapkan bahwa youtube sebagai sumber belajar yang akrab dengan mahasiswa dan memudahkan mencari informasi. Pangabean dan Halomoan (2018) dalam penelitiannya menemukan bahwa penggunaan youtube sebagai e-learning lebih berpengaruh signifikan terhadap hasil belajar mahasiswa daripada tidak menggunakan e-learning yang berbasis youtube. Wijayanto, Setiawan, Wahyudi, dan Firmansyah (2020) dalam penelitiannya menyatakan bahwa penggunaan media pembelajaran youtube (podcast) dapat meningkatkan hasil belajar siswa dengan sangat baik, hal ini karena platform youtube (podcast) dapat menampilkan tampilan yang lebih menarik dan tidak membosankan untuk disaksikan.

Dari hasil pembahasan tersebut, dari disimpulkan bahwa pemanfaatan youtube podcast sebagai media pembelajaran e-learning dapat memudahkan mahasiswa dalam mencari referensi dan lebih familiar dan mampu meningkatkan hasil belajar mahasiswa. Penggunaannya juga sangat cocok untuk pembelajaran jarak jauh dan model blended learning.

Selain karena pengaruh media youtube dan podcast, kehadiran birokrat dan praktisi dalam pembelajaran tentu saja memberikan dampak terhadap peningkatan aktivitas mahasiswa, keterampilan dosen dan meningatkan hasil belajar mahasiswa. Purwaningsih (2020) menyatakan bahwa pembelajaran blended learning dengan 
menggunakan inisiasi pembelajaran online melibatkan praktisi dapat meningkatkan kualitas pembelajaran. Lebih rinci, Ulfa, Kharisma, Sari (2020) menyatakan bahwa kehadiran praktisi pada perkuliahan di kampus bisa menjadi jembatan yang menghubungkan antara sisi pengetahuan akademiki dan permasalahan di lapangan kerja, sehingga memberikan bekal mahasiswa sebelum benar-benar memasuki dunia kerja atau permasalahan di dunia usaha dan dunia industri. Firomadhoni (2014) menyatakan kehadiran birokrat dalam perancangan bahan ajar tentu memberikan masukan yang baik terkait situasi terkini dan memberikan gambaran tentang kegiatan yang dilaksakan saat ini, dan masa depan sesuai dengan aturan yang berlaku di birokrasi Indonesia.

Jadi keberadaan praktisi dan birokrat dalam memberikan masukan yang positif sebagai jembatan antara dunia akademisi dengan dunia usaha dan industri. Akadimisi mampu menyelaraskan dengan perkembangan di dunia usaha dan industri serta kebijakan pemerintah dilihat dari sudut pandang para birokrat daerah, terutama yang berkaitan dengan pendidikan nonformal sehingga dapat menyusun bahan ajar yang memang mampu membekali mahasiswa sebagai persiapan memasuki dunia kerja.

\section{KESIMPULAN}

Penerapan model blended learning menggunakan media youtube podcast dengan melibatkan praktisi dan birokrat pendidikan nonformal dapat meningkatkan hasil belajar mahasiswa Program Studi Pendidikan Nonformal FKIP Universitas Bengkulu Semester 5 kelas A tahun ajaran 2021-2022 pada mata kuliah Analisis Kebijakan Pendidikan Nonformal. Penelitian tindakan kelas dilakukan dalam tiga siklus. Hasil penelitian menunjukan bahwa penerapan blended learning dengan menggunakan media youtube podcast dapat meningkatkan aktivitas mahasiswa menjadi lebih aktif, ini terlihat dari siklus 1 sebesar $71,6 \%$ atau berada pada kriteria tinggi, siklus 2 sebesar $82,6 \%$ atau berada dalam kriteria tinggi dan siklus 3 sebesar $87,2 \%$ atau berada dalam kriteria sangat tinggi. Begitu juga dengan keterampilan dosen dapat meningkat, pada siklus 1 sebesar 73,17\% atau kriteria baik, siklus 2 sebesar $80,5 \%$ atau kriteria baik dan siklus 3 sebesar $83,17 \%$ atau kriteria baik. Hasil belajar mahasiswa juga mengalami peningkatan. Pada siklus 1 ketuntasan minimal sebesar 66,67\% (belum tuntas), pada siklus 2 ketuntasan minimal sebesar 77,78\% (belum tuntas), dan siklus 3 sebesar 92,59\% (tuntas).

\section{DAFTAR PUSTAKA}

Andini, N. F. (2020). Dampak Pembelajaran Daring Bagi Mahasiswa Masa Pandemi Covid-19. Academia. Edu.

Fadilah, E, dkk. (2017). Podcast sebagai Alternatif Distribusi Konten Audio. Kajian Jurnalisme, Vol 1(1), 90-104

Firomadhoni, L. R. (2014). Upaya-upaya tim pengembang dalam pengembangan program pendidikan keaksaraan dasar metode baca Delila di BP-PAUDNI Regional II (Doctoral dissertation, Universitas Negeri Malang).

Iwantara, I.W, dkk. (2014). Pengaruh Penggunaan Media Video Youtube dalam Pembelajaran IPA terhadap Motivasi Belajar dan Pemahaman Konsep Siswa. Ejournal Program Pascasarjana Universitas Pendidikan Ganesha Program Studi IPA. Vol.4, 1-13 
Kemmis, \& Mc Taggart, R. (1988). The Action Research Planner. Victoria: Deakin University Press

Panggabean, S., \& Halomoan, T. (2018). Pengaruh media e-learning berbasis youtube terhadap hasil belajar mahasiswa pada mata kuliah analisis real prodi pendidikan matematika FKIP UMSU. In Prosiding SiManTap: Seminar Nasional Matematika Dan Terapan (pp. 25-30).

Purwaningsih, T. (2020). Penerapan blended learning melalui inisiasi pembelajaran online menggunakan website dan Google Hangout dengan melibatkan praktisi industri sebagai upaya peningkatan kualitas pembelajaran di kelas business environment. Refleksi Pembelajaran Inovatif, 1(2).

Purwanto, N. (2006). Prinsip-Prinsip dan Teknik Evaluasi Pengajaran. Bandung: PT. Remaja Rosdakarya

Rachmawati, F, dkk. (2019). Mengukur Efektivitas Podcast sebagai Media Perkuliahan Inovatif pada Mahasiswa. Justek: Jurnal Sains dan Teknologi. Vol 2(1), 38-44

Rohmanu, A, dkk. (2020). Kesiapan, Kompleksitas dan Harapan Pembelajaran Jarak Jauh: Perspektif Mahasiswa IAIN Ponorgo. Al-Tadzkiyyah: Jurnal Pendidikan Islam. 11(2) 221-241

Setiadi, E. F., Azmi, A., \& Indrawadi, J. (2019). Youtube Sebagai Sumber Belajar Generasi Milenial. Journal of Civic Education, 2(3), 313-323.

Setiani, A. (2020). Efektivitas Proses Belajar Aplikasi Zoom di Masa Pandemi dan Setelah Pandemi Covid-19. In Prosiding Seminar Nasional Pascasarjana (PROSNAMPAS) (Vol. 3, No. 1, pp. 523-530).

Sudjana, N. (2001). Penelitian dan Penilaian Pendidikan. Bandung: Sinar Baru

Tutiasri, R.P, dkk. (2020). Pemanfaatan Youtube Sebagai Media Pembelajaran Bagi Mahasiswa di Tengah Pandemi Covid-19. Jurnal Komunikasi, Masyarakat dan Keamanan, 2(2), 1-15

Ulfa, V. S., Kharisma, H. D., \& Sari, D. A. (2020). Optimasi Akademisi dan Mata Kuliah Teknik Kimia Melalui Peran Praktisi Industri.Prosiding Seminar Nasional Universitas Islam Syeck Yusuf 2020 (pp.1379-1383)

Wijayanto, P. S., Setiawan, W., Wahyudin, W., \& Firmansyah, A. (2020). Meningkatkan Hasil Belajar Siswa Melalui Media Youtube (Podcast) dengan Metode Pembelajaran Pendidikan Jarak Jauh pada Materi Komputer dan Jaringan Dasar di SMKN 3 Bandung. Jurnal Guru Komputer, 1(1), 50-62.

Zellatifanny, C.M. (2020). Tren Diseminasi Konten Audio on Demand melalui Podcast: Sebuah Peluang dan Tantangan di Indonesia. Jurnal Pekommas, vol. 5(2), 117132 
AKSARA: Jurnal Ilmu Pendidikan Nonformal

P-ISSN 2407-8018 E-ISSN 2721-7310 DOI prefix 10.37905

Volume 08, (1), January 2022

http://ejurnal.pps.ung.ac.id/index.php/Aksara 